\title{
Regional Scale Modelling of Solid Waste Flow in Storm Drains of Urban Cities: The Case Study of the Abiergué Watershed
}

\author{
Ndongo Barthelémy*, Fonteh Mathias Fru*, Ngu Jiofack Ludovic*, Ntankouo \\ Njila Roger César* \\ * (Department of Agricultural engineering, Faculty of Agricultural Sciences, University of Dschang, Cameroon)
}

\begin{abstract}
Floods are phenomena that become more frequent and more intense due to anthropogenic activities such as poor land use, improper waste management, uncontrolled urbanization, industrialization ... In developing countries, the drainage systems are most often limited (if not absent), inadequate or not adapted. Most of the storm drains are regularly filled with solid materials that are collected from the environment and conveyed by runoff. Waste management in developing countries is very poor and important fractions of the wastes produced are abandoned in nature thereby impacting severely on the environment.

The Abiergué watershed was targeted to study the process of the hydrological transformation of rainfall into runoff that conveys solid waste within a drainage system. The aim of this research was to develop a model that will enable the simulation of waste flow with respect to a specific rainfall pattern. It will permit to quantify the total solid wastes in circulation in a drainage system and as such provide appropriate and significant information on the role played by these wastes which can be used for engineering new adapted systems in developing countries. It was found that the solid domestic wastes and soil sediments evolved following a linear and a quadratic pattern respectively with respect to runoffs.
\end{abstract}

Keywords - Drainage system, models, runoff, solid domestic waste, soil sediment

\section{INTRODUCTION}

It has long been known that, as long humans have lived in settled communities, solid domestic waste generation has been an unavoidable and decisive issue both in developed and developing nations. As a result of poor land use and consumption habits, significant amounts of soil have eroded from landscape and the amount of solid domestic waste produced from households has as well considerably increased with subsequent delivery into the drainage system. These wastes affect the effective evacuation of storm water from drains thereby causing floods to occur. Domestic waste management constitute a thorn to most countries characterized by a developing economy. In most African cities the efficiency of waste collection structures barely reaches 50\% ([1]; [2]; [3]; [4]; [5]; [6]; [7]; [8]). A substantial amount of these waste still remain uncollected in nature.

Many inhabitants of cities characterized by a developing economy, carry out illegal practices as far as waste management is concerned. They practice different forms of unauthorized dumping: open dumping (dumping in open areas), fly dumping (dumping from vehicles), midnight dumping or wildcat dumping (dumping at night period) [9]. These wastes are regularly carried alongside with runoff and are most often abandoned in these structures which latter on significantly impact their functioning. Poor land use practices such as urban agriculture, quarrying, greatly affects the flow of sediments into receiving structures such as storm drains and water bodies.

The growing tendency of dumping waste in nature will continue to impact severely on the efficiency of storm drains and has to be considered in the mitigation of flood development in countries characterized by a developing economy [10]. Consequently, the specific objective of this research is the development of a mathematical model of the solid discharge flow within a drainage system.

\section{METHODOLOGY}

Situated utterly within Yaoundé, the watershed of Abiergué is located between latitudes $3^{\circ} 53^{\prime} 30^{\prime}$ ', 3 ${ }^{\circ} 54^{\prime} 0^{\prime}$ 'North and longitudes $11^{\circ} 26^{\prime} 30^{\prime}$ ', $11^{\circ} 30^{\prime} 00^{\prime}$ 'East. According to the latest administrative zoning (carried out in 2008), this watershed is found within the district of Yaoundé II and VII, department of Mfoundi, Center region, Cameroon, Africa. The localization of this watershed is as illustrated in fig 1. The Abiergue hydrography is characterised by a third order stream (Strälherhorton classification), an average bifurcation ratio of 3.7 and drainage density of $1.58 \mathrm{~km} / \mathrm{km}^{2}$. Fig 2 presents the hydrography of this basin shows a stream of the third order with an average bifurcation ratio of 3.7 [11]. The stream flows south - west, on a distance of about $8 \mathrm{~km}$, towards the Mefou River that it joins at the Nkolbisson district [12]; [13]. 


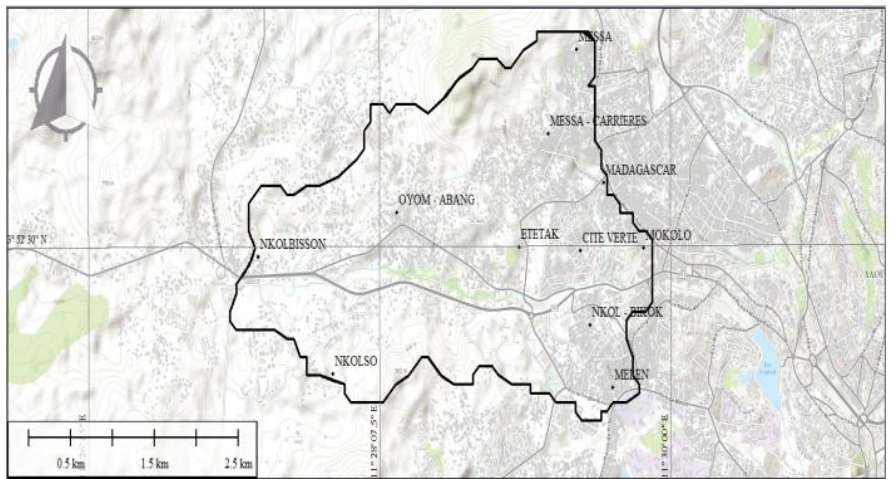

Figure 1: Localisation of the area of study

This watershed is characterized by a sloppy relief (ranging from 0 to $15 \%$ ), with the most abundant class being that of $0-4 \%$ [14]. The highest altitude of this watershed is $885 \mathrm{~m}$ and the minimum altitude is $610 \mathrm{~m}$.

Just like its mother town, the Abiergué watershed has a bimodal rainfall regime with two dry seasons and two wet seasons. The average annual precipitations in Yaoundé are about 1600 $\mathrm{mm}$. The inter-annual average monthly temperatures vary from $22.4{ }^{\circ} \mathrm{C}$ and $25.7{ }^{\circ} \mathrm{C}$ with 1500 - 1750 hours of annual sunshine [14]. The hydrographic network of the city is very dense with numerous drainage sub-basins. These ensure that the natural drainage of the city is very good [15].

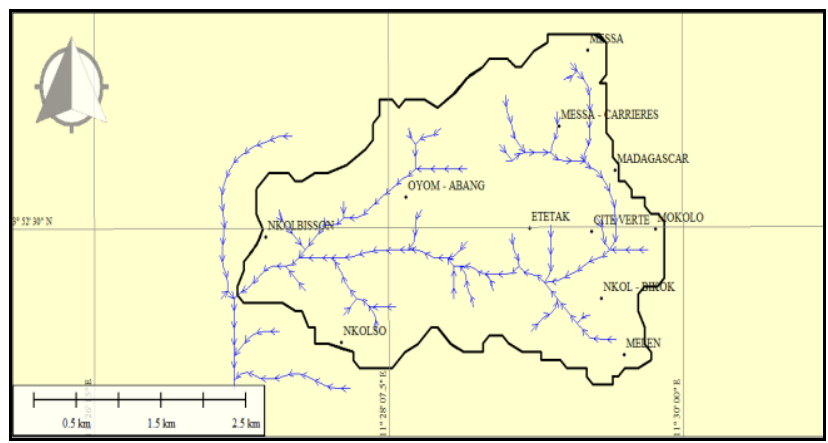

Figure 2: Hydrology of the watershed

The relief of the study area also has the main features found in Yaoundé which is that of: hills, low-lying areas with swamps etc. The population of the study area is estimated to be 201 677 inhabitants, with a growth rate of about $3.1 \%$ [16]. This rapid increase in population pushes people to seek and occupy land in risky areas (steep slopes, valleys, wetlands) of existing districts. Abiergué is a highly cosmopolitan area regrouping most of the ethnic groups of Cameroon.

\subsection{Data collection}

Many hydraulic engineers and geomorphologists have for long tried to establish relationships that could permit to determine the quantity of solid particles transported by runoff water within drainage systems. Many methods have been discovered ranging from empirical formulae to those involving the use of models. Some of these methods estimate the volume of sediments in a direct way and others in an indirect way utilizing hydraulic data of the channel in which water flows as well as its characteristics [17]. It is in this regard that soil traps (precisely the check dams and trenches) were used to assess the experimental parameters (solid domestic waste and soil sediments). Check dams, trenches are used for quantifying solid particles in runoff but can equally be used combined or individually depending on the objective of their use or of the study. Soil traps are temporary devices installed on a construction site to capture eroded or disturbed soil that is washed off during rain storms, and protect the water quality of a nearby stream, river, lake, or bay [18].

\subsection{Engineering and construction of check dams}

Check dams are structures designed to retain gross particles and can be made out of planks, metal or plastics. The check dams design for this research were made up of a wooden frame on which was attached wire gauze. Small spacing was chosen for the wire gauze. Indeed, the objective was not to prevent water from flowing but to retain gross particles and slow the flow of water. The wire gauze had the net spacing of $2 \mathrm{~cm}$. 
It is important to note that not all solid particles are responsible for storm drain blockages, suspended particles flow easily to main water bodies in the drainage basin meanwhile those of more significant size sometimes settle in these channels and their accumulations ends up by blocking the drains. The suspended material generally, can contribute in blockage of the channel only after the more significant ones or other solid materials such as solid domestic waste have already settled in and/or paralyzed the channel. That is why the present research focalized on those particles susceptible to initiate the blockage of the channel. It is from such judgment that the spacing of the wire mesh was established.

In natural drains, trenches (fig 3) were used together with check dams. Within the trench an additional wire gauze material was placed at its base. This material was to be the structure on which the transported solid material in the runoff which crossed the check dam was to be dropped on. It had to give the possibility for water to drain throughout easily leaving behind it the material of interest (soil particles). The wire gauze used here had a net spacing of $0.5 \mathrm{~cm}$.

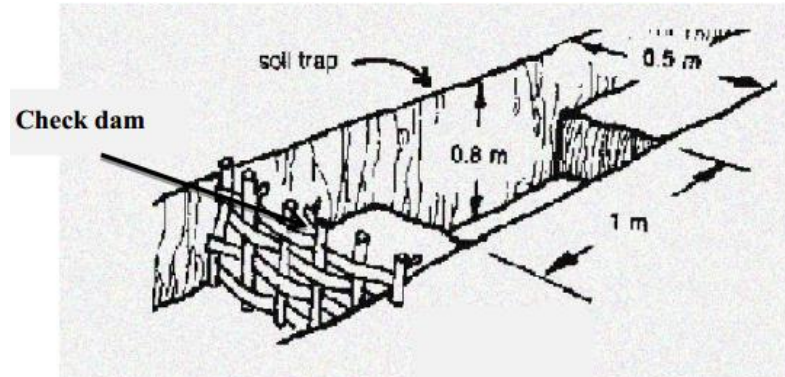

Figure 3: Soil trap (check dams and trench)

\subsection{Monitoring}

Fig 4 illustrates the 16 sampling points in the watershed that were chosen for collecting the solid wastes transported by runoff. Four neighborhoods were targeted for collecting the samples and in each of the neighborhood, soil traps were installed in two types of drains: Natural and artificial drain.

After every rain event, the content of the various storm drain were removed sorted, and their weights and volumes were determined in situ.

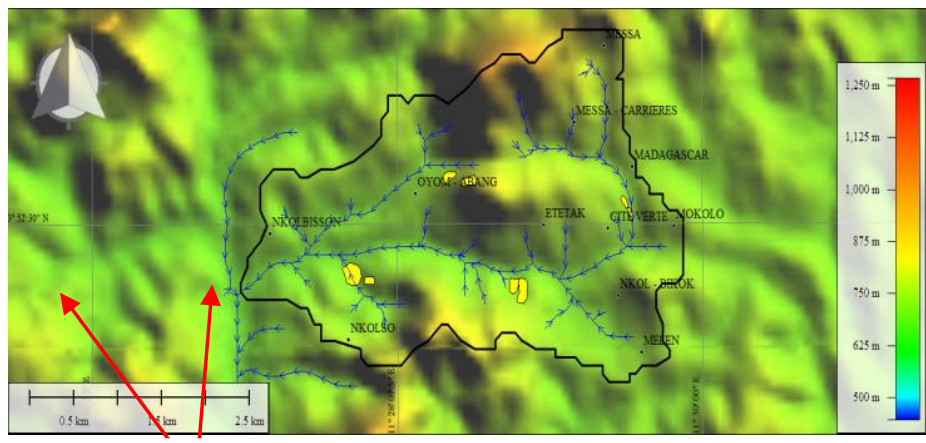

Sampling points

Figure 4: sampling points in the watershed chosen for collecting the solid wastes transported by runoff

\subsection{Modelling}

The collected data were processed with different computer software programs. The main purpose of working with these various software packages was to rapidly and efficiently determine the existence of any relationships between the different variables under study and if yes, how significant the relation was and of what nature. This was to enable the elaboration of mathematical models that will best describe this hydrological behavior within the drainage basin. In order to ascertain the causal effect of one of the variable upon the other, the freeware called ${ }^{\circledR}$ (version 3.1.0) was used. ${ }^{\circledR}$ is a software package for scientific development that uses a programming language specialized in calculations and statistical analysis [19]. In order to understand the hydrological process of the transformation of precipitation into runoff which later on, conveys waste within a drainage basin, the software program STELLA (version 10.0) was used. STELLA (an acronym for Structural Thinking Experimental Learning Laboratory with Animation) is a software package that permits to simulate the dynamic function of a liquid system, to 
follow their evolution [20]. This software package enabled to simulate within its environment this hydrological behavior. The simulation was to describe the behavioral pattern of one variable with respect to another (in case a relation existed) from which the nature of the relationship could be identified. The various variables processed in ${ }^{\circledR}$ to determine the existence of the relationship were used as entries for the model. The variables were: Precipitation; Solid domestic waste and Soil sediment.

A number of hypotheses were formulated for the exercise. The results (transformation process) generated from these interactions using STELLA which were to be closest to the data obtained from the field were that considered as the model. The rainfall was used in the models as the component responsible for conveying the waste (solid domestic wastes and soil sediments) particles but in reality, the volume of waste is found to evolve with respect to the effective rainfall which is, the part flowing directly when in contact with the soil (runoff). Within a drainage basin, rain is transformed into runoff with respect to a coefficient that depends on three main factors: slope, soil cover and type of soil. This runoff coefficient takes into consideration: Evaporation; Infiltration and storages in depressions. With respect to a surface area $\mathrm{A}$, the volume of runoff is linked to rainfall $\mathrm{R}$ as shown on equation 1 .

$$
\mathrm{R}=\frac{V_{\text {out }}}{\left(c_{Y} \times A\right)}
$$

Where

$$
\begin{array}{ll}
- & \mathrm{V}_{\text {out }}=\text { Volume of runoff at the outlet }\left(\mathrm{m}^{3}\right) \\
- & \mathrm{A}=\text { Surface Area }\left(\mathrm{m}^{2}\right) \\
- & \mathrm{Cr}=\text { Runoff coefficient }
\end{array}
$$

$\mathrm{Cr}$ can be looked upon as the ratio between the volumes of water that flows at the outlet $\mathrm{V}_{\text {out }}$ of a point to the total volume of water $\left(\mathrm{V}_{\text {tot }}\right)$ that fell in that drainage basin [21]

$$
\begin{aligned}
& \boldsymbol{C r}=\frac{\text { Vout }}{\text { Vtot }} \\
& \text { But } \mathbf{V}_{\text {tot }}=\mathbf{R} \times \mathbf{A} \\
& \text { Replacing (3) in (2) } \\
& \boldsymbol{C r}=\boldsymbol{V o u t} \times\left(\frac{1}{\boldsymbol{R} \times \boldsymbol{A}}\right) \\
& \boldsymbol{V o u t}=\boldsymbol{C r} \times \boldsymbol{R} \times \boldsymbol{A}
\end{aligned}
$$

The 'Cr' used in this case was obtained from previous studies [8]. It was chosen based on the nature of the drainage basin. ' $A$ ' was determined with the use of GIS tools and ' $R$ ' was obtained from local meteorological stations. With equation (5), $\mathrm{V}_{\text {out }}$ was assessed for the various settlement types identified in the drainage basin and later on used to determine the constants of the model so as to have the volume of waste as a function of volume of runoff; waste $=\mathrm{fn}\left(\mathrm{V}_{\text {out }}\right)$. This was computed with the help of Microsoft Excel.

\subsection{Testing and validating the model}

Once the models were designed, simulations were carried out to compare the significance of their result. Other collection campaigns were organised to collect waste data from the same experimental sites for a significant period of time. Graphs were drawn presenting both results (simulated and field waste) from which various trends were observed and the closeness of their results were determine. In case a significant difference existed between the theoretical and practical results a calibration would be necessary. The Pearson's correlation was used to figure it out using the statistical tool SPSS.

Pearson's correlation coefficient is a statistical measure of the strength of a relationship between paired data. In a sample it is denoted by $r$ and is by design constrained as follows [22]

\section{$\mathbf{1} \leq \mathbf{r} \leq \mathbf{1}$}

Correlation is an effect size and so can verbally describe the strength of the correlation using the guide suggested by [22] for the absolute value of $r$ (correlation coefficient):

- .00-.19 "very weak"

- .20-.39 "weak"

- .40-.59 "moderate"

- .60-.79 "strong"

- .80-1.0 "very strong”

\subsection{Rainfall/Runoff measurement}

The model was initially developed making use of runoff values computed from rainfall and runoff coefficient. However to have results that translate the field reality, in the course of the validation of the model, a rangefinder (fig 5) developed from the university of Dschang in Cameroon was used to assess on the field the various values of runoff. 


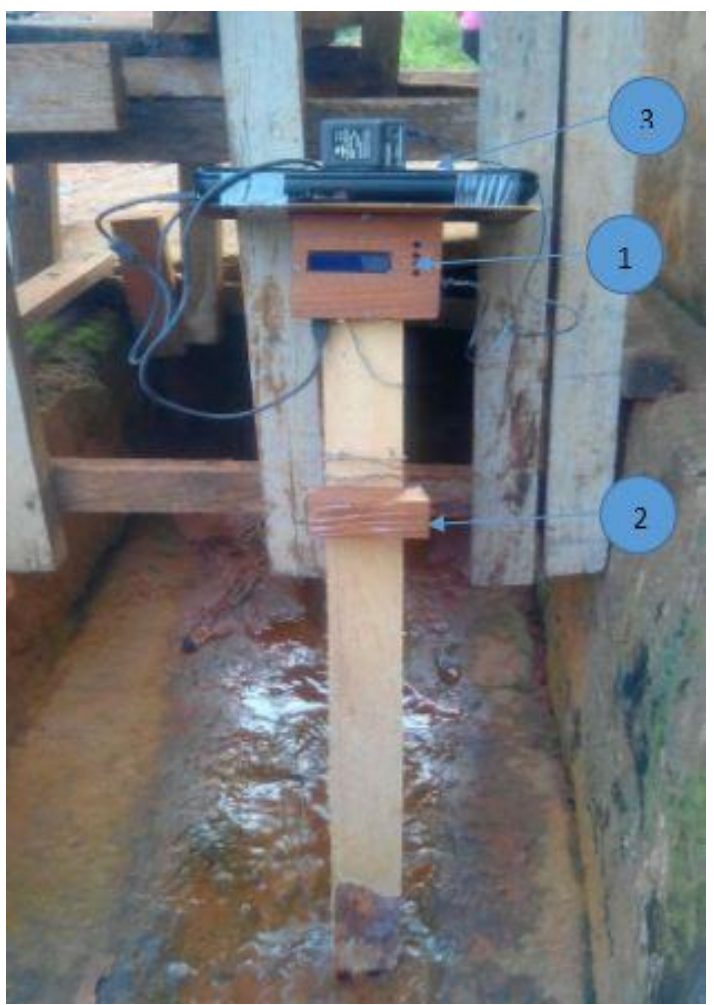

Figure 5: Rangefinder and it components

$1=$ The emitter unit of the rangefinder.

$2=$ The receiver unit of the rangefinder.

$3=$ The PC unit within which the collected data were stored.

This instrument functions following the principle of echo-localization system of some mammals like bats or dolphins. It involves emitting waves (from emitter of the rangefinder) that travels a certain distance (with regard to the capacity of the instrument) to the targeted element (runoff or drain) and once it meets the obstacle, it bounces on its surface and is sent back to the instrument (receiver of the rangefinder) that records data.

\section{RESULTS}

\subsection{Relationship between experimental variables}

The generation of box and whisker plot graphs with ${ }^{\circledR}$ (fig 6) showed that the variations between the variables were very high, enough to admit the existence of a relation between the variables despite the fact that it was not very explicit to permit to identify what type of relationship it was. The analysis was pushed further using STELLA which could readily tell on what bases and how far these variables were related. Using STELLA, a modelled scenario of the hydrological transformation was carried out, so as to bring forth the nature of the relationship between the various variables under study. Going from the idea that they was no clear direct link between the variables, a good number of assumptions were made by proposing various types of equations (linear, exponential...) as well as nature of variables (cumulative values or not...) and running the simulations, comparing at each time the results with that collected on the field. Final results were obtained when their average significance values were greater than 0.95 .

STELLA revealed that the solid domestic waste and soil varied following two distinct patterns: a Cumulative Linear pattern for solid domestic waste 'sdw' $\left(\mathrm{V}_{\mathrm{sdw}}=\mathrm{a} \times \mathrm{R}+\mathrm{b}\right)$ and a Cumulative Quadratic pattern for soil sediments $\quad\left(\mathrm{V}_{\text {soil sediments }}=\right.$ $\left.a \times R^{2}+b \times R+c\right)$ with respect to precipitation itself a Cumulative function,

Where:

Vsdw $=$ Volume of Solid domestic waste

Vsoil $=$ Volume of soil sediment

$\mathrm{a}, \mathrm{b}$ and $\mathrm{c}=$ constants

$\mathrm{R}=$ Rainfall (precipitation) 


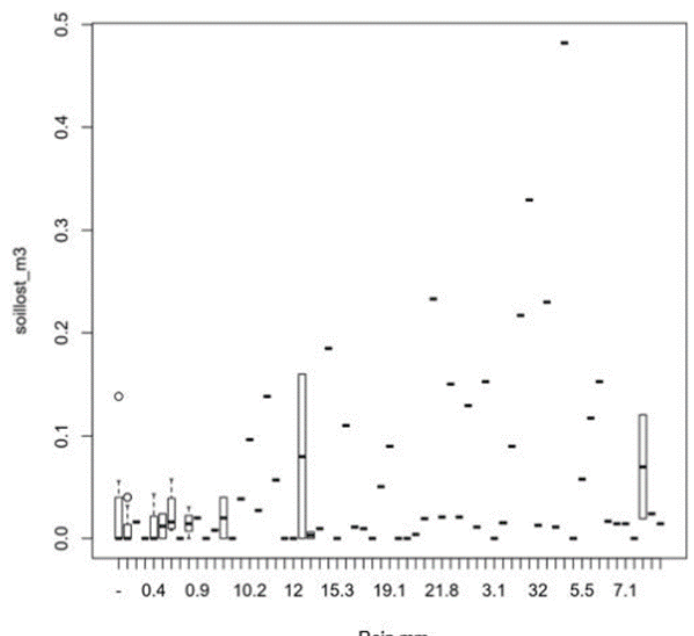

a) Variation between soil sediment and rain

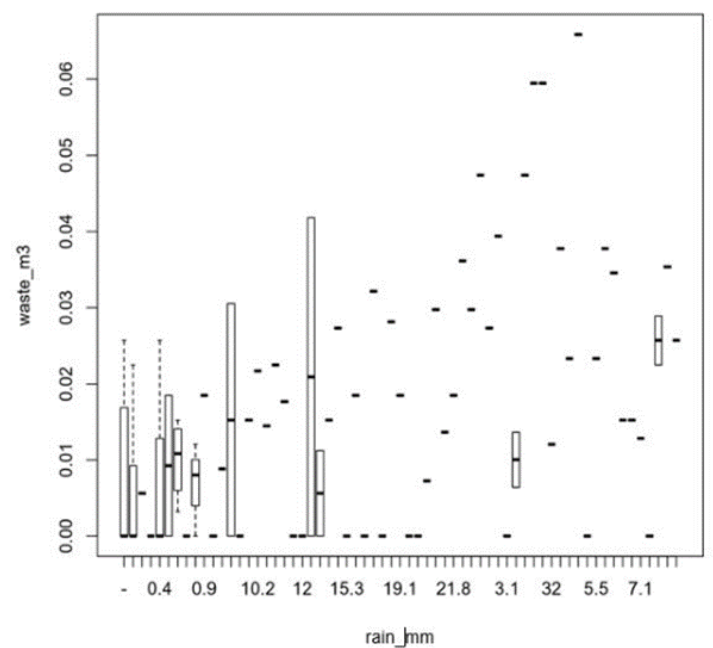

b) Variation between solid domestic waste and rain

Figure 6: Variation between and solid waste and rainfall

TABLE 1 presents the values of the various coefficient obtained after analysis of the data using runoff as the conveying agent obtained from field measurements.

Table 1: Equations of the relationship between wastes and precipitation

\subsection{Simulations}

\begin{tabular}{|c|c|c|c|}
\hline Neighbourhood & $\begin{array}{l}\text { Nature } \\
\text { of drain }\end{array}$ & Solid domestic waste model & Soil sediment model \\
\hline Etetack: & Artificial & $V_{\text {solid dementicnatat }}=2.7 \times R+0.002$ & $V_{\text {sol iodmas }}=1,9 \times R^{2}+3,2 \times R-0,015$ \\
\hline Oyomabang & Artificial & $V_{\text {solid demusicic nzats }}=4,2 \mathrm{R} R+0,050$ & $V_{\text {sol ioimes }}=.0,7 \times R^{2}+2,7 \times R-0,600$ \\
\hline Nkolso & Artificial & $V_{\text {solid demsitic nzata }}=4.1 \times R+0,040$ & $V_{\text {sol holmes }}=-1,3 \times R^{2}+4,8 \times R+0,401$ \\
\hline Cite Verte & Artificial & $V_{\text {solid demstic nata }}=3,6 \times R+0,010$ & 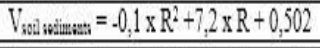 \\
\hline Etétack & Natural & $V_{\text {solis demsitic nzata }}=1,4 \times R+0,006$ & $V_{\text {sol horimas }}=-2,2 \times R^{2}+9,1 \times R+0,012$ \\
\hline Oyomabang & Natural & $V_{\text {soil didessic nzats }}=4,0 \times R-0,740$ & $V_{\text {sol avimas }}=-0,1 \times R^{2}+1,6 \times R+0,700$ \\
\hline Nkolso & Natural & $V_{\text {noili d demstic nati }}=1,1 \times R-0,510$ & $V_{\text {sol avimas }}=-0,7 \times R^{2}+8,2 \times R+0,502$ \\
\hline Cite Verte & Natural & 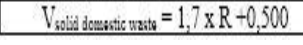 & $V_{\text {sol wimimas }}=-1,0 \times R^{2}+3,0 x R+0,030$ \\
\hline
\end{tabular}

The results of the volume of wastes obtained through simulations with these equations were compared with the volumes of waste collected from the field. Fig 7 and fig 8 illustrate graphically the trend of both curves. 

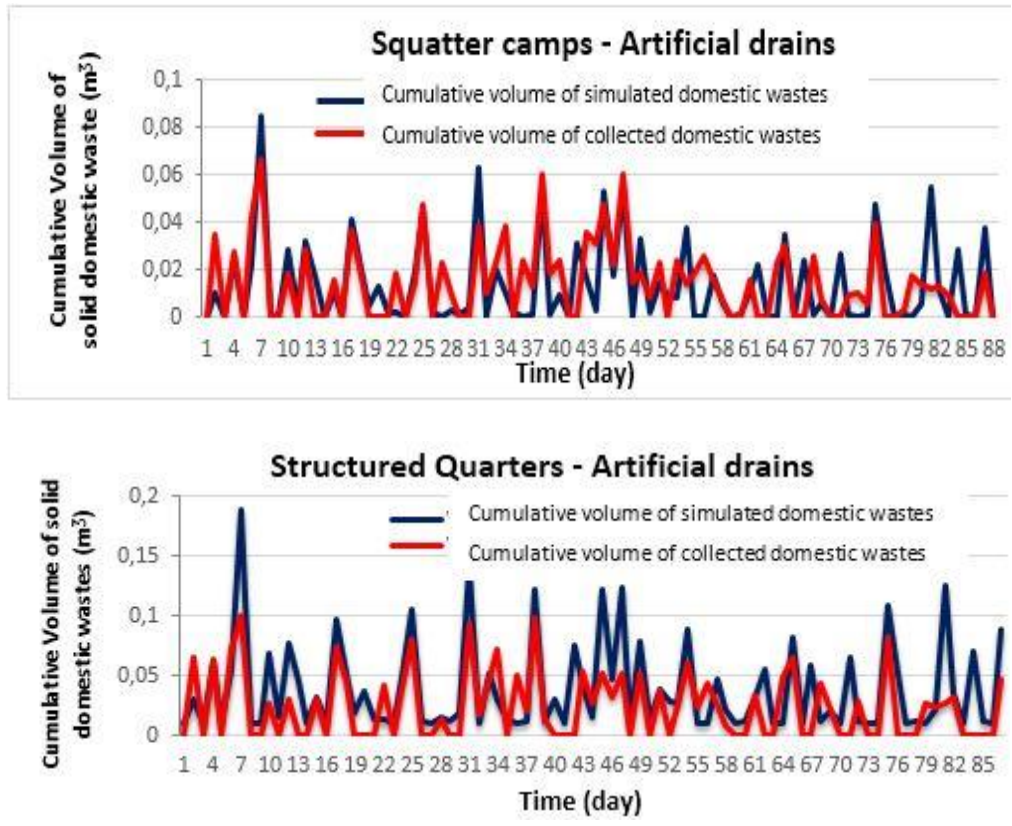

Figure 7: Correlation between values of simulated and collected solid domestic wastes in artificial drains of structured and squatter camps
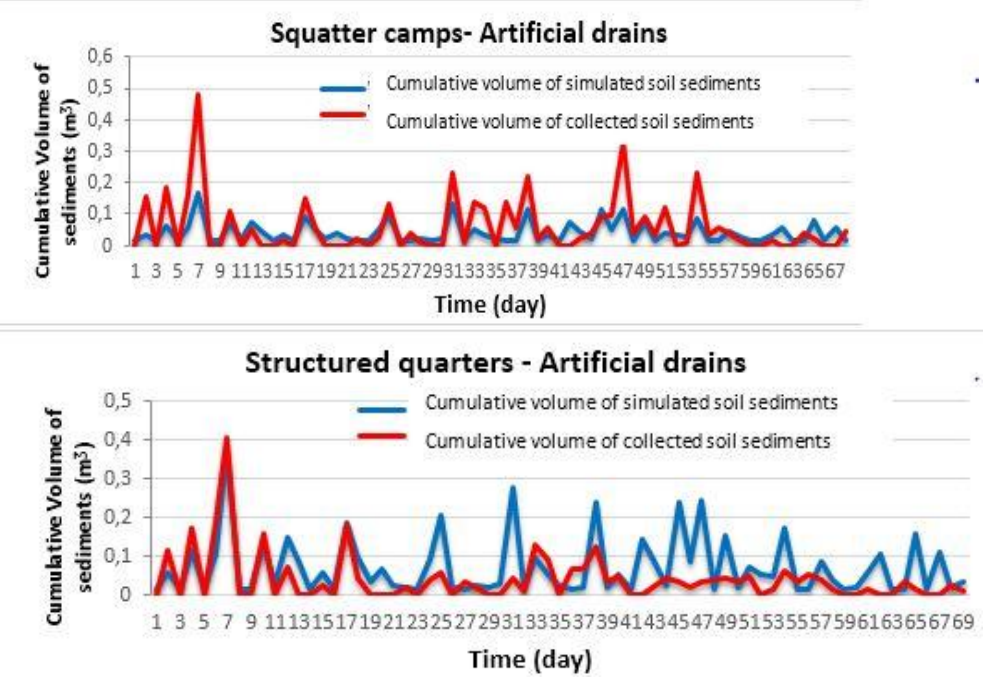

Figure 8: Correlation between values of simulated and collected soil sediments in artificial drains of structured and squatter camps

For the squatter (or spontaneous) and structured settlement, the correlation coefficient obtained were as follows (with regard to [23]'s guide):

- For $S D W$

0.666 for Etetack (Spontaneous settlement),

0.551 for Oyomabang (Structure settlement),

$$
\begin{aligned}
& =\text { strong } \\
& =\text { moderate } \\
& \text { = moderate } \\
& \text { = strong } \\
& \text { = strong } \\
& =\text { strong } \\
& =\text { moderate } \\
& =\text { moderate }
\end{aligned}
$$

0.718 for Cité Verte for (Structure settlement).

The correlation coefficient is found to be varying between moderate and strong with a more or less balance between the structured and spontaneous 
neighbourhood. This result expresses the precision of the model and as such it can be concluded that no adjustment is necessary for the various models.

\subsection{Impact of waste on the volume of runoff}

In spontaneous neighbourhoods, the increase in volume of runoff accounted for, by solid domestic wastes and soil sediments range from 6 to $7 \%$ for Etetack and 2 to $9 \%$ for Nkolso. This implies that for spontaneous settlements, the increase ranges from $2-9 \%$. In structured settlement, the increase in volume of runoff accounted for by solid domestic waste and soil sediment are 4 to $10 \%$ for Cité Verte and $4 \%$ for Oyomabang. This implies that for structured settlements, the increase ranges from 4$10 \%$.

\section{CONCLUSION}

From a practical point of view, this research develops a novel approach in the contribution of the fight against floods via the development of a local models that predicts the amount of solid waste in circulation in an urban environment with respect to runoff. The model was tested and validated under practical circumstances. The simulations permitted to evaluate the impact of the solid discharge in the increase of the total volume of runoff.

The results of this research can be an extra tool used by decision makers, geomorphologists, hydrologists and water engineers for implementation in various aspects or domains. This notwithstanding, the applicability of this model should be further investigated for other urban watersheds.

\section{REFERENCES}

[1] Sotamenou, J., 2005. Efficacité de la collecte des déchets ménagers et agriculture urbaine et périurbaine dans la ville de Yaoundé au Cameroun. Mémoire de Diplôme d'Etudes Approfondies Programme de Troisième Cycle Interuniversitaire en Economie, Université de Yaoundé II, Cameroun, 144 pp.

[2] Rotich, K.H., Yonsheng, Z., Jun, D., 2006. Municipal solid waste management challenges in developing countries. Kenyan study: Waste management, 9pp. Retrieved May $11, \quad 2016 \quad$ from www.sciencedirect.com.

[3] Ta-Thuy, T., 1998. Pour une gestion efficiente des déchets dans les villes africaines, les mutations à conduire. Les cahiers PDM. Cotonou, Bénin, 59pp.

[4] Benrabia, N., 2003. Le Financement du service de Gestion des déchets ménagers en Afrique, présentation orales à l'atelier Africités 3, Yaoundé, Cameroun. Retrieved $\begin{array}{llll}\text { April 23, } & 2016 \quad \text { from }\end{array}$

http://sud.hypotheses.org/198

[5] Bernard, K., 2002. Indexation du financement des déchets sur la consommation d'électricité à Abidjan. Présentation orales a l'atelier régional sur la gestion des déchets en Afrique, Cotonou, Bénin.

[6] EAMAU (Ecole Africaine des Métiers de l'Architecture et de l'Urbanisme), 2002. Opportunités et contraintes de la gestion des déchets à Lomé: Les dépotoirs intermédiaires, Rapport final. Lomé, Togo, $54 \mathrm{pp}$.

[7] Doublier, G., 2003. Tri sélectif et valorisation des déchets urbains de la ville de Ndjamena. Rapport final, Ndjamena. Tchad, $70 \mathrm{pp}$

[8] Ould, T, M., Ould, M. Z., 2003. Projet d'appui aux petits transporteurs des déchets solides du quartier Basra à Nouakchott, Rapport final. Nouakchott, Mauritania. 84pp.

[9] EPA (Environmental Protection Agencies), 2013. Illegal Dumping Control. National Pollutant Discharge Elimination System. Retrieved August 15, 2013, from http://cfpub.epa.gov/npdes/stormwater/men uofbmps/index.cfm?action=browse \& Rbutto $\mathrm{n}=$ detail $\& \mathrm{bmp}=31$

[10] Ndongo, B., Fonteh, M. F., Ngu, J. L., Lako, M. S., 2016. Solid Discharge Modeling in an Urbanized Drainage Basin within a Developing Country: the Abiergué Drainage Basin Case Study: International Journal of Advance Research in Science, Engineering and Technology (IJARSET); ISSN: 2350-0328.V-3, I-6, 6pp.

[11] Ngu, J. L., 2014. Impact of waste management on floods in an urbanised drainage basin. Professional Master's thesis. Dept of Agricultural Engineering, Faculty of Agriculture, University of Dschang, Dschang, Cameroon, 127 pp.

[12] Ntep, R., 2002. Pollution physico-chimique et microbiologique d'un hydrosystème en milieu urbain: Cas de l'Abiergué. M.Sc. thesis. University of Yaoundé I; Yaoundé, Cameroon, 78 pp.

[13] Kouam, K. G. R., 2009. Enjeux Sanitaires, Socio-Economiques et Environnementaux liés à la Réutilisation des Eaux Usées dans le Maraîchage Urbain à Yaoundé au Cameroun: Cas du Bassin Versant de l'Abiergué. M.Sc. thesis. Université of liège, Wallonia, Belgium, $89 \mathrm{pp}$.

[14] Kouam, K. G. R., 2013. Vers une gestion rationnelle de l'eau dans une situation 
complexe d'urbanisation anarchique dans un pays en développement : Cas du Bassin Versant de l'Abiergué. Ph.D. dissertation. Université de liège, Wallonia, Belgium, 265 $\mathrm{pp}$

[15] INS., 2013. Etude pilote sur la pollution des eaux de surface et souterraines à Yaoundé et son impact sur la santé des populations riveraines (epess) rapport technique. Retrieved April 06, 2014 from http://www.statisticscameroon.org/downloa ds/La_population_du_Cameroun_2010.pdf

[16] Berger, L., 2010. Elaboration d'un plan de déplacements urbains de la ville de Yaoundé. Rapport diagnostic version final, $329 \mathrm{pp}$.

[17] Pinto, M. D., 2008. Aménagements hydroélectriques et impacts sur la dynamique des flux d'eau et de sédiments. Le cas du haut Paraná, Brésil. Thèse de doctorat. Université Lumière Lyon 2, Lyon, France. Retrieved July 30, 2013, from http://theses.univlyon2.fr/documents/lyon2/ 2008/pintomartins_d\#p=0\&a=top

[18] IIRR (International Institute of Rural Reconstruction), $1995 . \quad$ Resource Management for Upland Areas in Southeast Asia: An Information Kit. 207 pp.
[19] Chiquet, J., 2012. Introduction au logiciel

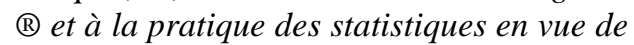
l'analyse des données issues de la biologie. Ecole doctorale « du génome au organisme», Université d'Evry, Evry, PAY, 102 pp.Retrieved march 15, 2014, from http://stat.genopole.cnrs.fr/_media/member s/jchiquet/teachings/slides_intro_r.pdf.

[20] Len, L., 2013. Introduction to Stella. Retrieved August 9, 2013, from http://ceeserver.cee.cornell.edu/lwl3/cee351 0/homework/STELLA\%20intro(2013).pdf

[21] RF (République Françaises)., 2008. Gestion des eaux pluviales dans les projets d'aménagement: conception des projets et constitution des dossiers d'autorisation et de déclaration au titre de la police de l'eau. Guide technique Volume 2, $61 \mathrm{pp}$.

[22] Statstutor, 2016. Pearson's correlation. Statistics support for students: Correlation. Retrieved April 11, 2016 from www.statstutor.ac.uk.

[23] Evans, J. D., 1996. Straightforward statistics for the behavioral sciences. Ed Pacific Grove: Brooks/Cole Pub. Co., (C) 1996. Retrieved January 28, 2016 from http://www.worldcat.org/title/straightforwar d-statistics-for-the-behavioralsciences/oclc/32465263 